\title{
Electrochemical Behaviour of a Gold Film- Glassy Carbon Electrode for Determination of Chromium (VI)
}

\author{
NEVILA Broli*, LORETA Vallja ${ }^{\dagger}$, MAJLINDA Vasjari, ${ }^{\dagger}$, \\ * University of Tirana, Faculty of Natural Science, Department of Chemistry \\ Address: Bulevardi “Zogu I", No. 2, postal code 1001, Tirana, Albania
}

corresponding author:Tel : + 35568 2092552, email : nevila.broli@fshn.edu.al;

loreta.vallja@fshn.edu.al ; majlinda.vasjari@fshn.edu.al

\begin{abstract}
A gold nanostructured film modified glassy carbon electrode $\left(\mathrm{Au}_{\text {film }} / \mathrm{GCE}\right)$ was developed for the determination of chromium (VI) in water sample. GCE was immersed into $\mathrm{HAuCl}_{4}$ solution $\left(10^{-3} \mathrm{M}\right)$ and electrodeposition of thin gold layer was conducted at $-0.4 \mathrm{~V}$ (vs $\left.\mathrm{Ag} / \mathrm{AgCl}\right)$ for 10 min. The strong affinity between $\mathrm{Au}$ and $\mathrm{Cr}$ species resulted with increasing of $\mathrm{Cr}$ (VI) signal, compared with the bare glassy carbon electrode. The electrodepositing time, type of supporting electrolyte, $\mathrm{pH}$, the scan rate, modulation amplitude, and modulation time were optimized using differential pulse anodic stripping voltammetry (DP-ASV). The calibration graph using accumulation time of $120 \mathrm{~s}$ was linear from 10 to $120 \mu \mathrm{gL}^{-1}$ with a sensitivity $1.3 \times 10^{-2} \mu \mathrm{A} / \mu \mathrm{gL}^{-1}$. Under optimum experimental conditions, a good correlation coefficient $\mathrm{R}^{2}=0.9971$, and a low detection limit $5.5 \mu \mathrm{g} / \mathrm{L} \mathrm{Cr}(\mathrm{VI})$ was obtained. The signal was reproducible with a relative standard deviation $\pm 4.5 \%$. The developed $\mathrm{Au}_{\text {film }} / \mathrm{GCE}$ sensor was applied for the $\mathrm{Cr}$ (VI) determination of in sewage water samples.
\end{abstract}

Keywords: Chromium (VI); thin gold film; glassy carbon electrode and differential pulse anodic stripping voltammetry 


\section{Introduction}

Chromium is a metallic element usually found in aquatic systems in two different oxidation states, $\mathrm{Cr}$ (III) and $\mathrm{Cr}(\mathrm{VI})$ with completely different natures. Chromium (III) in trace amounts is an essential supplement in the body and combines with various enzymes to transform proteins, sugar and fat, while chromium(VI) which, depending on the $\mathrm{pH}$, is available as $\mathrm{CrO}_{4}{ }^{2-}, \mathrm{HCrO}_{4}{ }^{-}, \mathrm{H}_{2} \mathrm{CrO}_{4}$ or $\mathrm{Cr}_{2} \mathrm{O}_{7}{ }^{2-}$ is toxic, mutagenic and carcinogenic. The oxidation state of chromium has a remarkable effect on its toxicity and also its bioavailability (Kachoosang and Compton 2013). Therefore, as Thacker et al 2012 reported, determination of chromium (VI) is much more important than chromium (III), and the design of an analytical method which is capable of selective measurement of chromium (VI) is of great importance. According to El-Shahawi et al. 2005 and 2008, the chemical speciation of chromium in environmental samples is necessary for accurate assessments of the pollution source and levels. Chromium(VI) is usually determined by UV-VIS spectrophotometry by means of diphenylcarbazide in acidic solutions (Rudel and Terytze 1999).

Electrochemical techniques are considered to be powerful methods. Voltammetric methods are advantageous in speciation of chromium because they offer a low detection limit and the determinations can be carried out without any additional separation step. In particular, adsorptive stripping voltammetry (AdSV) is of interest due to its high sensitivity and selectivity according to Liu et al. 2007. Svancara et al. 2004 and Biswas et al. 2017 developed some of electrochemical methods and techniques for Cr(VI) detection. Also Welch et al. 2005 studied the reduction mechanism of $\mathrm{Cr}(\mathrm{VI})$ at solid electrodes in acidic media and its analytical application. Dai et al. 2006 reported that metal nanoparticles have shown superior or advantageous properties for a wide range of technological applications and they provide three important functions for electroanalysis: improved mass transport, high effective surface area, and catalytic properties. Many methods were reported to synthesize metal nanoparticles including reduction with different reagents as Wang et al. 2006 studied, UV light and electron-beam irradiation as Bertino et al. 2004 reported, and electrochemical methods studied by Liu et al. 2008. In this work, a gold thin film modified glassy carbon 
electrode $\mathrm{Au}_{\mathrm{film}} / \mathrm{GCE}$ was prepared by electrochemical method, in order to improve analytical performance of Glassy Carbon Electrode (GCE) for quantitative determination of Cr (VI) in water. The influence of several physicochemical (pH, type of supporting electrolyte) and instrumental (deposition time, scan rate, modulation amplitude) parameters on the DP-ASV response has been evaluated. From the estimated results this sensor could be an alternative method for a sensitive detection of $\mathrm{Cr}(\mathrm{VI})$ in water sample with DP anodic stripping voltammetry.

\section{${ }^{\dagger}$ Contact details of corresponding author}

Tel.: +355682092552

e-mail: nevila.broli@fshn.edu.al 


\section{Experimental}

Material and Methods:

Differential pulse Anodic stripping voltammetric mode (DP-ASV) were conducted using Electrochemical Analyzer (MEC-12B). The glassy carbon electrode modified with $\mathrm{Au}$ - nano film was used as working electrode. $\mathrm{Ag} / \mathrm{AgCl}$ electrode (saturated $\mathrm{KCl}$ ) was used as reference electrode and a platinum wire as auxiliary electrode. The Au-nano film onto the surface of the working GCE was prepared by electrodeposition before each electrochemical measurement (see Procedure below). Standard solutions of $\mathrm{Cr}$ (VI) $\left(100 \mathrm{mg} / \mathrm{L}^{-1}\right)$, hydrogen chloride $\mathrm{HCl} 0.1 \mathrm{M}, \mathrm{HNO}_{3} \quad 0.1 \mathrm{M}, \mathrm{H}_{2} \mathrm{SO}_{4} 0.1 \mathrm{M}$ and all other compounds were purchased from Sigma Group Chemical Reagents Co. Ltd, and used without any further purification. A solution of $\mathrm{HAuCl}_{4}(0.108 \mathrm{~g} \mathrm{Au}$ in $100 \mathrm{ml}$ $\mathrm{HAuCl}_{4}$ ) in $0.1 \mathrm{M} \mathrm{HCl}$ was used in electrochemical cell to deposit $\mathrm{Au}$ - nano film at the GCE surface. All reagents used were analytical grade and solutions were prepared with distilled water.

\section{Preparation of the Aufilm/GCE}

The $\mathrm{Au}_{\text {film }} / \mathrm{GCE}$ sensor was prepared by electrodeposition. Initially the glassy carbon electrode was rinsed with water to remove any residual polishing material. Than the surface of the electrode is polished gently with the $\mathrm{Al}_{2} \mathrm{O}_{3}$ powder with particle sizes $0.01 ; 0.5 ; 1.0 \mu \mathrm{m}$, purified with distilled water and ethanol $(98 \%)$. The procedure for the electrodeposition of Au-nanofilm at GCE was adapted from published reports Liu et al. 2007. The GCE was immersed into solution containing $15 \mathrm{~mL} \mathrm{HCl} 0.1 \mathrm{M}$ and 140 $\mu \mathrm{L}$ of $\mathrm{HAuCl}_{4}\left(0.108 \mathrm{~g}\right.$ of $\mathrm{Au}$ in $100 \mathrm{ml}$ of $\mathrm{HAuCl}_{4}$ solution $)$ and deposition was 
conducted at the potential of $-0.4 \mathrm{~V}(\mathrm{vs} \mathrm{Ag} / \mathrm{AgCl})$ for $10 \mathrm{~min}$. Thereafter the stripping step was performed till $+0.6 \mathrm{~V}$ in stirring condition for $25 \mathrm{~s}$.

\section{Electrochemical Measurements}

The electrochemical measurements were performed using modified $\mathrm{Au}_{\mathrm{film}} / \mathrm{GCE}$ and unmodified GCE electrode applying differential pulse anodic stripping voltammetry (DP-ASV) technique. In the electrochemical cell containing $15 \mathrm{ml} \mathrm{HCl} 0.1 \mathrm{M}(\mathrm{pH}=1)$ as a supporting electrolyte anodic stripping voltammograms were recorded between -0.2 to $+0.8 \mathrm{~V}$, by applying differential pulse mode with the deposition time $120 \mathrm{~s}$, scan rate $100 \mathrm{~m} \mathrm{~V} / \mathrm{s}$, step potential $4 \mathrm{mV}$, amplitude $20 \mathrm{mV}$, and modulation time $5 \mathrm{~ms}$. During the deposition step the potential was kept at $-0.2 \mathrm{~V}$ for 120 sec. After recording background voltammogram successive standard solution of chromium (VI) was added into electrochemical cell and the voltammogram were recorded after each addition. The same electrochemical conditions were used to determine $\mathrm{Cr}(\mathrm{VI})$ in the sewage water samples.

\section{Sewage Water Analysis and Recovery}

Sewage water samples were collected near an industrial factory of leather processing and cleaning. Firstly, the water sample was purified by a vacuum filtration process as the sample contained many solid suspensions. $2 \mathrm{~mL}$ of filtered sewage water were introduced into electrochemical cell containing $15 \mathrm{ml} \mathrm{HCl} 0.1 \mathrm{M}$. Recovery experiments were performed by spiking standard $\mathrm{Cr}$ (VI) stock solution to the water sample following by the determination of analyte using DP-ASV experiments. 


\section{Results and Discussion}

\section{Electrochemical response of $\mathrm{Cr}(\mathrm{VI})$ on $\mathrm{Au}_{\mathrm{film}} / \mathrm{GCE}$ sensor}

The effect of the gold film in the electrochemical detection of chromium (VI) was studded using the differential pulse anodic stripping voltammetry in a solution $0.1 \mathrm{M}$ $\mathrm{HCl}(\mathrm{pH}=1)$ containing $\mathrm{Cr}(\mathrm{VI})$. The successive voltammograms were recorded between -0.2 to $+0.8 \mathrm{~V}$ using a scan rate $100 \mathrm{mV} / \mathrm{s}$, step potential $4 \mathrm{mV}$, amplitude $20 \mathrm{mV}$ and modulation time $5 \mathrm{~ms}$. Although the anodic peaks of $\mathrm{Cr}(\mathrm{VI})$ using modified and bare electrode in the electrochemical cell contained $100 \mu \mathrm{g} \mathrm{L}^{-1}$ of $\mathrm{Cr}$ (VI) appeared at potential $+0.3 \mathrm{~V}$ the highest peak was obtained with modified electrode. This can be attributed to the strong affinity between $\mathrm{Au}$ and $\mathrm{Cr}$.

\section{Optimization of experimental parameters}

The optimization of DP-ASV instrumental parameters influencing in the current response of analyte it is very important step in the development of electroanalytical methodology. The effect of different parameters such as $\mathrm{pH}$, type of supporting electrolyte, and accumulation time was investigated in order to optimize analytical performance of $\mathrm{Au}_{\text {film }} / \mathrm{GCE}$ sensor for determination $\mathrm{Cr}(\mathrm{VI})$ in water solution. All experiments are performed in $50 \mu \mathrm{g} \mathrm{L}^{-1} \mathrm{Cr}(\mathrm{VI})$ and step potential of $4 \mathrm{mV}$.

The response obtained using modified sensor, $\mathrm{Au}_{\text {film }} / \mathrm{GCE}$ in $\mathrm{Cr}(\mathrm{VI})$ solution applying different accumulation time (30s; 60s; 120s; 180s), is shown in the Figure 1. It can be seen that the response increases linearly up to $120 \mathrm{~s}$ accumulation time, and thereafter 
decreases, reflecting the electrode surface saturation. Therefore, an accumulation time of $120 \mathrm{~s}$ was used for all further measurements.

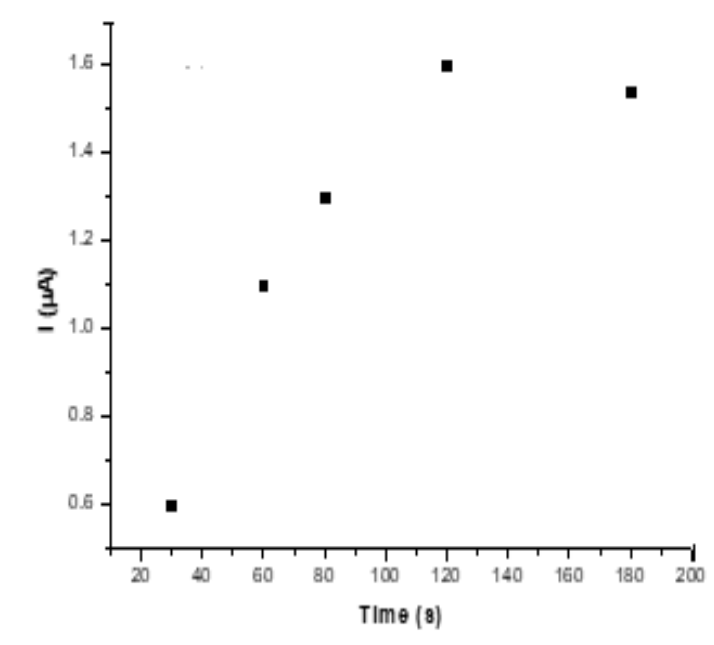

Figure. 1 Effect of the accumulation time (30s; 60s;120s; 180s) at $\mathrm{Au}_{\mathrm{film}} / \mathrm{GCE}$, in $0.1 \mathrm{M}$ $\mathrm{HCl}$ for concentration $50 \mu \mathrm{g} \mathrm{L}^{-1} \mathrm{Cr}(\mathrm{VI}$

Selection of suitable supporting electrolyte is important on sensor response because has effect on kinetics of the charge transfer processes. Various inorganic acids were used including hydrochloric, nitric and sulfuric $0.1 \mathrm{M}$ in order to investigate their impact on the electroanalytical signal of $50 \mu \mathrm{g} \mathrm{L}-1 \mathrm{Cr}$ (VI) solution. The best (position shift to negative potential, height and width) anodic peak for $\mathrm{Cr}(\mathrm{VI})$ using $\mathrm{Au}_{\text {film/GCE was obtained when }}$ hydrochloric acid is used as the supporting electrolyte (figure 2a). The difference between the sensitivity of $\mathrm{Cr}(\mathrm{VI})$ in $\mathrm{HNO}_{3}, \mathrm{HCl}$ and $\mathrm{H}_{2} \mathrm{SO}_{4}$ according to Roohollah and Richard 2013 is probably due to the difference in the diffusion rate of species to the electrode surface. Also it may reflect adsorption on the electrode and the variation between acids 
suggests that the adsorption of anions plays a significant role in the reduction mechanism as Roohollah and Richard 2013 mention in their study. In this prospect this electrolyte was used for subsequent experiments.

The effect of $\mathrm{pH}$ on peak current using modified sensor was demonstrated in the diagram fig $2 \mathrm{~b}$, concentration of $\mathrm{HCl}$ vary from 0.001 to $0.1 \mathrm{M}$, which correspond $\mathrm{pH} 3$ to 1 , respectively.

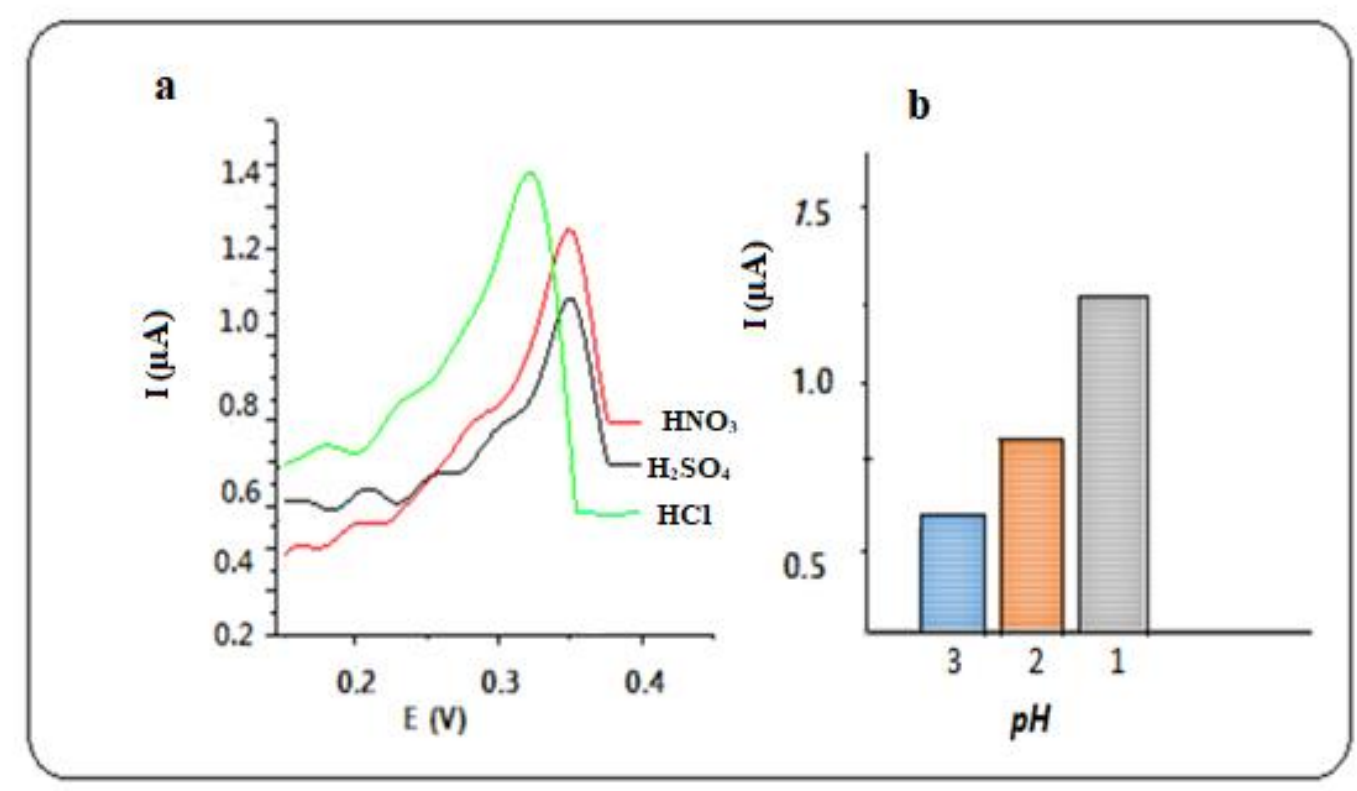

Figure. 2 a) Anodic stripping voltammograms of $50 \mu \mathrm{g} \mathrm{L}^{-1} \mathrm{Cr}(\mathrm{VI})$ at various electrolyte.

b) Effect of $\mathrm{pH}$ on the peak current for the determination of $\mathrm{Cr}(\mathrm{VI})$ on $\mathrm{Au}_{\text {film-GCE }}$

It is obviously shown from diagram that the highest signal in solution of $\mathrm{Cr}(\mathrm{VI}) 50 \mu \mathrm{g}$ $\mathrm{L}^{-1}$ using $\mathrm{Au}_{\text {film }} / \mathrm{GCE}$ sensor was obtained at concentration $0.1 \mathrm{M} \mathrm{HCl}(\mathrm{pH}=1)$. Lower signal of anodic peak current explained by toindicate proton-dependent process as it is 
reported elsewhere by Yamadaa et al 2008. For this reason, lower analytical signal was obtained in the case of lower concentration of indifferent electrolyte $(0.001 \mathrm{M} \mathrm{HCl})$, possibly because of the low concentration of protons. Therefore, $0.1 \mathrm{M}$ hydrochloric acid solution was used as the optimum concentration of supporting electrolyte for the rest of this study.

Some experimental condition parameters such as scan rate and modulation magnitude were optimizing in order to obtained the best signal with high sensitivity toward analyte Cr VI. With increasing of modulation amplitude is observed that the peak current increases gradually up to $50 \mathrm{mV}$, and then it remained constant but the form of the peak becomes wider. It was choosing $20 \mathrm{mV}$ as the most suitable amplitude to give the highest and sharper peak. Also by increasing the scan rate from 50 to $150 \mathrm{mV} / \mathrm{s}$, peak current increased proportionally up to $100 \mathrm{mV} / \mathrm{s}$. With increasing the scan rate more than $100 \mathrm{mV} / \mathrm{s}$ no effect to the peak was observed. To obtain the highest signal of $\mathrm{Cr} \mathrm{VI}$ scan rate $100 \mathrm{mV} / \mathrm{s}$ was chosen in further experiments. According to the results presented above in all subsequent experiments regarding evaluation of analytical parameters and real sample analysis were used optimal conditions listed in table below. In table 1 are summarizes the operating conditions optimized for the DP-ASV analysis of Cr(VI) using a $\mathrm{Au}_{\text {film-GCE. }}$ 
Table. 1 The operating conditions optimized for $\mathrm{Cr}(\mathrm{VI})$ determination with DP-ASV using a $\mathrm{Au}_{\text {film-GCE sensor }}$

\begin{tabular}{|c|c|}
\hline $\begin{array}{l}\text { Experimental conditions: } \\
\text { (DP-ASV) }\end{array}$ & Optimized Value \\
\hline Supporting electrolyte & $\mathrm{HCl} 0.1 \mathrm{M}$ \\
\hline $\mathrm{pH}$ & 1.0 \\
\hline Deposition time & $120 \mathrm{~s}$ \\
\hline Deposition potential & $-0.2 \mathrm{~V}$ \\
\hline Detection potential $^{\mathrm{a}}$ & $+0.3 \mathrm{~V}$ \\
\hline Scan rate & $100 \mathrm{mV} / \mathrm{s}$ \\
\hline Potential scan & -0.2 to $0.8 \mathrm{~V}$ \\
\hline Modulation amplitude & $20 \mathrm{mV}$ \\
\hline Modulation time & $5 \mathrm{~ms}$ \\
\hline
\end{tabular}

a vs. $\mathrm{Ag} / \mathrm{AgCl}$, saturated $\mathrm{KCl}$

\section{Analytical Parameters}

The analytical performance of modified sensor $\mathrm{Au}_{\mathrm{film}} / \mathrm{GCE}$ for the determination of Cr(VI) were estimated by DP-ASV technique under optimal conditions. The differential pulse anodic striping voltammogrames for different concentrations of Chromium (VI) were illustrated in figure $3 \mathrm{a}$. The calibration plot is linear over the range from 10 to 120 $\mu \mathrm{g} \mathrm{L}^{-1}$. Limits of detection calculated based on three times the standard deviation of the baseline resulted $5.5 \mu \mathrm{g} \mathrm{\textrm {L } ^ { - 1 }}$. Respectively, the calibration curves and correlation coefficients are $\mathrm{y}=0.07593+0.01396 \mathrm{x}$ and $\mathrm{R}^{2}=0.9971$ corresponding the accumulation time of $120 \mathrm{~s}$ (fig $3 \mathrm{~b}$ ). The relative standard deviation for $\mathrm{Cr}(\mathrm{VI})$ determination at a concentration $120 \mu \mathrm{g} \mathrm{L}^{-1}$, was $4.7 \%(\mathrm{n}=4)$. 


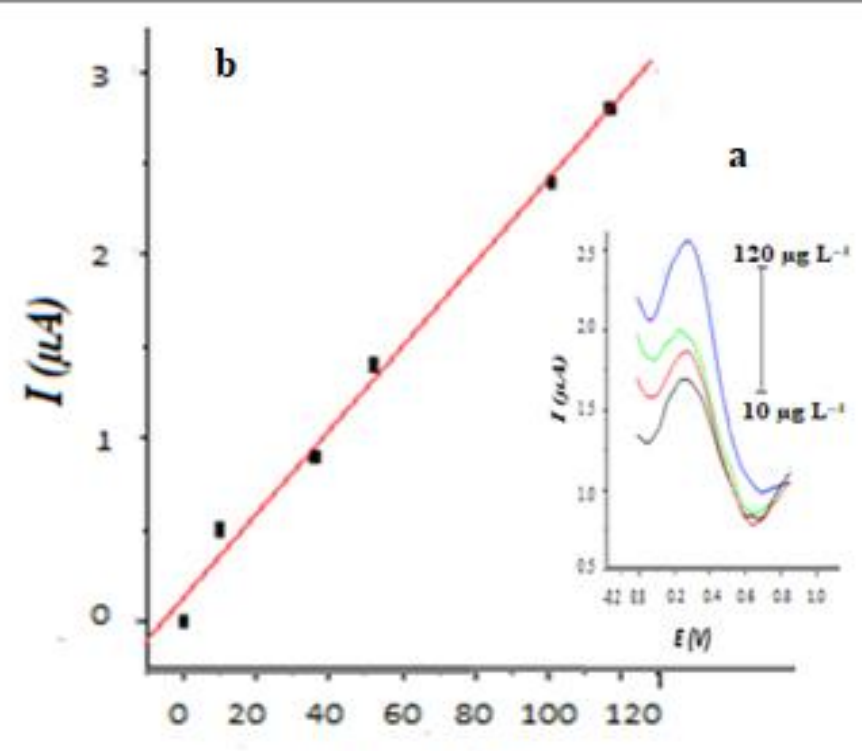

$c\left(\mu \mathrm{g} \mathrm{L}^{-1}\right)$

Figure. 3 a) DP-AS voltammograms registered with $\mathrm{Au}_{\text {film }} / \mathrm{GCE}$ electrode in $\mathrm{HCl} 0.1$ $\mathrm{M}, \mathrm{t}_{\mathrm{dep}}=120 \mathrm{~s}$, poteciacial from -0.2 to $0.8 \mathrm{~V}$ in different concetration of $\left.\mathrm{Cr}(\mathrm{VI}) . \mathbf{b}\right)$ Calibration curve of various $\mathrm{Cr}(\mathrm{VI})$ concentration

The results obtained in this work demonstrate the improvement of the reproducibility and sensitivity for determination of $\mathrm{Cr}$ (VI) using $\mathrm{Au}_{\text {film }} / \mathrm{GCE}$ sensor and DP-ASV. 
Table. 2 Analytical performance of various modified electrodes for $\mathrm{Cr}(\mathrm{VI})$ determination.

\begin{tabular}{|c|c|c|c|c|}
\hline Modified electrode & Method & LOD $\left(\mu \mathrm{g} / \mathrm{L}^{-1}\right)$ & $\operatorname{LDR}\left(\mu \mathrm{g} / \mathrm{L}^{-1}\right)$ & Reference \\
\hline & & & & Richtera et al \\
\hline \multirow[t]{2}{*}{ Electrochemically activated GCE } & DPV & 6.25 & $20.8-13000$ & 2016 \\
\hline & & & & Metters et al \\
\hline \multirow[t]{3}{*}{ Gold screen printed macro electrode } & LSV & 228 & $520-84240$ & 2012 \\
\hline & & & & Tsai and Chen \\
\hline & $\mathrm{CV}^{\mathrm{c}}$ & 104 & $260-5200$ & 2008 \\
\hline
\end{tabular}

AuNP-ITO electrode ${ }^{d}$

Amperometry $\quad 5.2 \quad 26-2600$

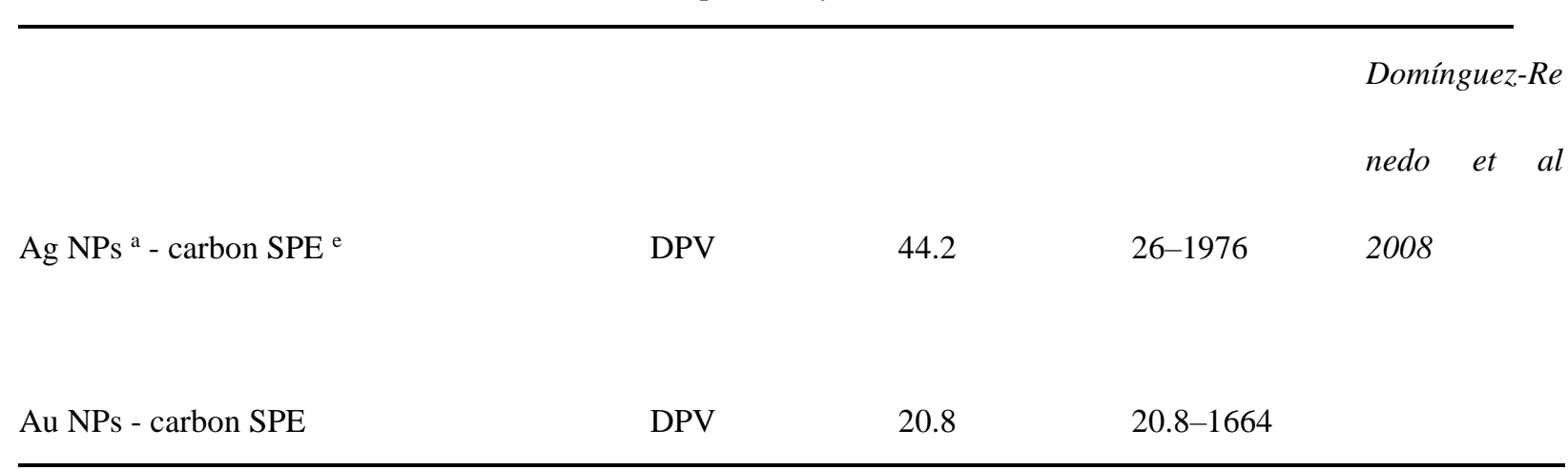

\begin{tabular}{|c|c|c|c|c|}
\hline \multirow[b]{2}{*}{ Ag plated-GCE } & \multirow[b]{2}{*}{ DP-ASV } & \multirow[b]{2}{*}{5.2} & \multirow[b]{2}{*}{$18.2-2080$} & \multirow{2}{*}{$\begin{array}{l}\text { Stojanović } \\
\text { et al } 2018\end{array}$} \\
\hline & & & & \\
\hline & & & & Hallam et a \\
\hline \multirow[t]{2}{*}{ Graphite screen printed electrode } & LSV & 18.7 & 99.8-998.4 & 2010 \\
\hline & & & $10-120$ & This \\
\hline $\mathrm{Au}$ film-GCE & DP-ASV & 5.5 & work & \\
\hline
\end{tabular}


For comparative purposes in table 2 are listed various publications which report the analytical performance of the modified electrodes for $\mathrm{Cr}$ (VI) analysis. By the data reported the sensitivity of the method studied in this work shows advantages relating with sensitivity and low detection limit compared with reported electroanalytical methods referred. Regarding other analytical application procedures such as reproducibility, linearity, simplicity of the modification procedures is comparable with other methods.

\section{Analysis of a real sample}

The modified glassy carbon electrode $\left(\mathrm{Au}_{\text {film }} / \mathrm{GCE}\right)$ was applied to $\mathrm{Cr}(\mathrm{VI})$ determination in sewage water sample. A solution of the sample was acidified with nitric acid and a portion of $2 \mathrm{~mL}$ diluted in $15 \mathrm{~mL} \mathrm{HCl} 0.1 \mathrm{M}$ was used for analysis. The content of Chromium was determine using standard addition methods and the recoveries of the added $\mathrm{Cr}(\mathrm{VI})$ were studied. The recoveries results are used as quality control of the analytical determination of $\mathrm{Cr}$ in real samples taken near an industrial factory of leather processing and cleaning. The signal of the sample solution before spiking $\mathrm{Cr}(\mathrm{VI})$ was firstly recorded (Fig. 4) and then additions of $\mathrm{Cr}(\mathrm{VI})$ were done to the solution and the voltammogrames are recorded. 


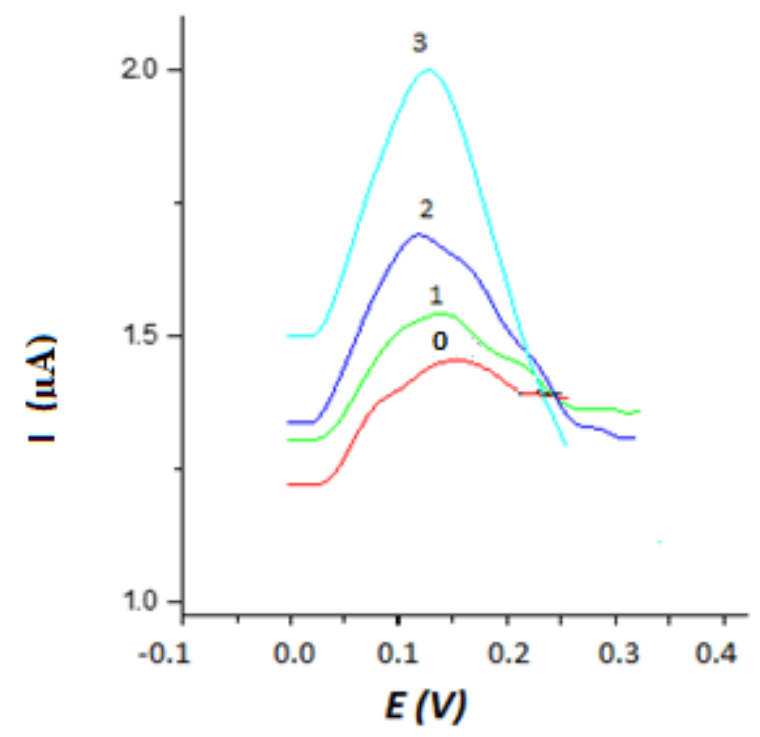

Figure. 4 DP-AS Voltammograms for standard additions of $\mathrm{Cr}(\mathrm{VI})$ in a sewage water sample, (0) sample signal before spiking and in concentrations (1)30, (2) 60, (3) $88 \mu \mathrm{g} / \mathrm{L}^{-1}$

$$
\mathrm{Cr}(\mathrm{VI})
$$

Voltammetric signal related to additions of Cr(VI), from 30 to $88 \mu \mathrm{g} \mathrm{L}^{-1}$ are shown in Fig. 4. The increase in the anodic signals is obtained with increasing the concentration of Cr(VI). The recovery results of analyses are given in Table 3, together with the total contents of chromium found by $\mathrm{Au}_{\text {film }} / \mathrm{GCE}$ in sewage solution.

Table. 3 Recovery test with sewage water samples

\begin{tabular}{cccc} 
Sample & $\mathbf{C r}(\mathbf{V I})$ & $\mathbf{C r}(\mathbf{V I})$ & Spike \\
$($ sewage water $)$ & Added & Found & Recovery \\
$\left(\mu \mathrm{gL}^{-1}\right)$ & & & $(\%)$ \\
& $\left(\mu \mathrm{gL}^{-1}\right)$ & $\left(\mu \mathrm{gL}^{-1}\right)$ & \\
\hline Chromium & 88 & $86.1 \pm 0.8$ & \\
Concentration & & & 100.3 \\
$150 \pm 0.6$ & 176 & $176.5 \pm 0.5$ & \\
\hline
\end{tabular}


The concentration of $\mathrm{Cr}$ in analyzed samples taken near an industrial factory of leather processing and cleaning resulted $150 \pm 0.6 \mu \mathrm{gL}^{-1}$ much higher than the allowance level of $\mathrm{Cr}$ in surface water according to U.S. EPA, 1998). The obtained recoveries of $\mathrm{Cr}(\mathrm{VI})$ added in concentrations of 88 and $176 \mu \mathrm{gL}^{-1}$ were $97.3 \%$ and $100.3 \%$ with RSD from $4.8 \%$ to $5.4 \%$, respectively. The results suggest that this method allows for $\mathrm{Cr}(\mathrm{VI})$ determinations in the presence of excess of $\mathrm{Cr}(\mathrm{III})$ and also can be easily adopted for routine analysis of chromium(VI).

\section{Conclusions}

A gold thin film- glassy carbon electrode $\left(\mathrm{Au}_{\mathrm{film}} / \mathrm{GCE}\right)$ is studied using DP-ASV for determination of chromium (VI) in liquid discharges of the leather processing industry. This method has advantages regarding the low cost for the fabrication of modified sensor, simple preparation, wide linear calibration zone, sensitivity and lowest limit of detection. It has been shown that, after proper optimization of the experimental conditions, the electrode prepared was suitable for the determination of $\mathrm{Cr}(\mathrm{VI})$ with high sensitivity and good reproducibility. The method developed was applied to real samples which gave satisfactory results and recovery of $97.8 \%$ obtained for a concentration of $88 \mu \mathrm{gL}^{-1}$. We can recommend that the proposed sensor can be easily applied for analysis of chromium (VI) in industrial and environmental polluted water. 


\section{References}

1. M. F Bertino, R. R Gadipalli, J. G Story, and C. G Williams. Appl. Phys. Lett. 85, 6007 (2004); https://doi.org/10.1063/1.1836000

2. P Biswas, A KumarKarn, P Balasubramanian, P. G. Kale: A review. Biosensors and Bioelectrinics. Volume 94, 15, Pages 589-604 (2017). https://doi.org/10.1016/j.bios.2017.03.043

3. R M Cespon-Romero, M C Yebra-Biurrun, M P Bermejo-Barrera. Anal Chim Acta 327: 37(1996)

4. X Dai , G G Wildgoose, Ch Salter, A Crossley, R G Compton. Electroanalysis Using Macro-, Micro-, and Nanochemical Architectures on Electrode Surfaces. Anal Chem ;78 (17):6102-8. (2006) doi: 10.1021/ac060582o.

5. O Domínguez-Renedo, $\mathrm{L}$ Ruiz-Espelt, $\mathrm{N}$ García-Astorgano, $\mathrm{M} \quad \mathrm{J}$ Arcos-Martínez. Talanta; 76:854-858. (2008) DOI: 10.1016/j.talanta.2008.04.036

6. M.S El-Shahawi, S.S.M Hassan, A.M Othman, M.A Zyada, M.A El-Sonbati. Anal. Chim. Acta, 534, 319-326. (2005)

7. M.S Elshahawi, S.S.M Hassan, A.M Othman, M.A ElSonbate. J Microchem., 89, 13-19.(2008).

8. P.M Hallam, D.K Kampouris, R.O Kadara and C.E Banks. Analyst, 2010, 135, 1947-1952. (2010) DOI: 10.1039/C0AN00228C

9. S.M Hassan, A.H Kamel, A-G Amr, M AbdelwahabFathy. and M. A Al-Omar. Molecules 2020, 25, 629; (2020) doi:10.3390/molecules25030629 
10. R.T Kachoosang and R.G Compton. Sensors and Actuators B: Chemical Volume 178, Pages 555-56. (2013).

11. B Liu, L Lu, M Wang and Y Zi . J. Chem. Sci., Vol. 120, No. 5, September 2008, pp. 493-498 (2008)

12. G Liu, J. Y-Y Lin, Y. $\mathrm{H}$ Wu. and $\mathrm{Y}$ Lin. Environmental Science \& Technology 41. pp8129-8134 (2007). https://pubs.acs.org/doi/10.1021/es071726z

13. J.P Metters, R.O Kadara and C.E Banks. Analyst; 137, 896-902 (2012). https://doi.org/10.1039/C2AN16054D

14. L Richtera, H. V Nguyen, D Hynek, J Kudr and V Adam. Analyst, 141, 5577-5585. (2016) https://doi.org/10.1039/C6AN00983B

15. R Rudel, K Terytze. Chemosphere 39: 697(1999).

16. Z ${ }^{\mathrm{a}}$,Stojanović Z, ${ }^{\mathrm{b}}$ Koudelkova E, ${ }^{\mathrm{b}} \mathrm{D},{ }^{\mathrm{b}, \mathrm{c}}$ Sedlackova Hynek, L ${ }^{* b, c}$ Richtera and V Adam. Anal. Methods, (2018) DOI: 10.1039/C8AY01047A.

17. I Svancara P, Foret, K Vytras. Talanta; vol 64; pp 844-852 (2004).

18. S.B Thacker, J.R Qualters, L.M Lee. MMWR Surveill Summ, 61, 3-9 (2012).

19. M-C Tsai and P-Y Chen. Talanta, 76(3):533-9. (2008) doi: 10.1016/j.talanta.2008.03.043

20. U.S.Environmenal Protection Agency. Toxicological (1998) Review of Hexavalent Chromium.National Center for Environmental Assessment,Office of Research and Development, Washington, DC.

21. S Varatharajan, S Berchmans \& V Yegnaraman. J Chem Sci 121, 665. (2009) https://doi.org/10.1007/s12039-009-0080-1

22. R N Vyas. and B Wang. Int J Mol Sci. 2010; 11(4): 1956-1972 (2010). 
23. A.L Wang, H.B Yin, M Ren, X.N Cheng, Q.F Zhou, X.F Zhang. Elsevier. Acta Metarllurgica Sinica. Volume 19, Issue 5, Pages 362-370 (2006).

24. C M Welch, C E Banks, A O Simm, R G Compton.. Anal Bioanal Chem; 382(1):12-21. (2005) doi: 10.1007/s00216-005-3205-5.

25. D Yamadaa, T. A Ivandinia, M Komatsuc, A Fujishimad, Y Einagaa. Journal of Electroanalytical Chemistry 615 145-153 (2008). 